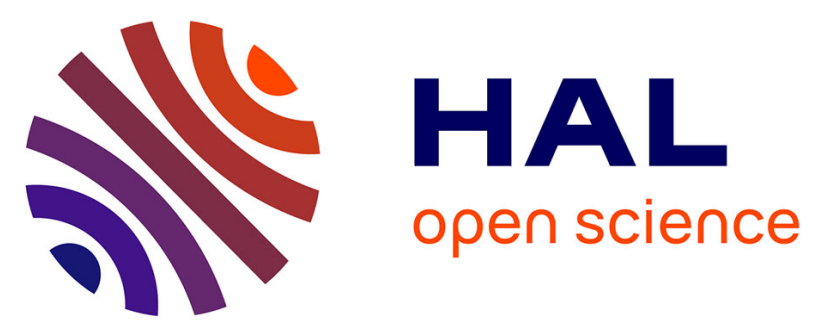

\title{
Occurrence of triterpenyl acetates in soil and their potential as chemotaxonomical markers of Asteraceae
}

Marlène Lavrieux, Jérémy Jacob, Claude Le Milbeau, Renata Zocatelli, Kazuo

Masuda, Jean-Gabriel Bréhéret, Jean-Robert Disnar

\section{- To cite this version:}

Marlène Lavrieux, Jérémy Jacob, Claude Le Milbeau, Renata Zocatelli, Kazuo Masuda, et al.. Occurrence of triterpenyl acetates in soil and their potential as chemotaxonomical markers of Asteraceae. Organic Geochemistry, 2011, 42 (11), pp.1315-1323. 10.1016/j.orggeochem.2011.09.005 • insu-02292350

HAL Id: insu-02292350

https://hal-insu.archives-ouvertes.fr/insu-02292350

Submitted on 8 Oct 2019

HAL is a multi-disciplinary open access archive for the deposit and dissemination of scientific research documents, whether they are published or not. The documents may come from teaching and research institutions in France or abroad, or from public or private research centers.
L'archive ouverte pluridisciplinaire HAL, est destinée au dépôt et à la diffusion de documents scientifiques de niveau recherche, publiés ou non, émanant des établissements d'enseignement et de recherche français ou étrangers, des laboratoires publics ou privés. 


\section{Occurrence of triterpenyl acetates in soil and their potential as chemotaxonomical markers of Asteraceae}

Marlène Lavrieux ${ }^{\mathrm{a}, \mathrm{b}, *}$, Jérémy Jacob ${ }^{\mathrm{b}}$, Claude Le Milbeau ${ }^{\mathrm{b}}$, Renata Zocatelli ${ }^{\mathrm{b}}$, Kazuo Masuda $^{c}$, Jean-Gabriel Bréheret ${ }^{\mathrm{a}}$, Jean-Robert Disnar ${ }^{\mathrm{b}}$

a Institut des Sciences de la Terre d'Orléans, Université François-Rabelais de Tours/Université d'Orléans, CNRS/INSU UMR 6113, Faculté des Sciences et Techniques, Parc Grandmont, 37200 Tours, France

' Institut des Sciences de la Terre d'Orléans, Université d'Orléans / Université François-Rabelais de Tours, CNRS/INSU UMR 6113, 1A rue de la Férollerie, 45071 Orléans Cedex 2, France

${ }^{\mathrm{c}}$ Laboratory of Phytochemistry, Showa Pharmaceutical University, Machida, Tokyo 194-8543, Japan

\section{HIGHLIGHTS}

Pentacyclic triterpenyl acetates occur in soil

The literature indicates they are discriminant biomarkers for Asteraceae.

Their potential as chemotaxonomic tracers in palaeoenvironmental studies is discussed 


\begin{abstract}
As a part of a wider study aimed at determining new molecular biomarkers in soils and sediments that could be specific for distinct vegetation types with respect to unravelling past changes in land use, we analysed the neutral lipid content of soil developed in the catchment of a small lake in central France. The ketone/acetate lipid fraction of soil under pasture or meadow contained a series of pentacyclic triterpenyl acetates with a wide structural diversity, most being reported in soil for the first time. The restricted number of potential plant sources of triterpenyl acetates (some produced by a single species) underlines the potential of triterpenyl acetates as new biomarkers to track past vegetation change in palaeoenvironmental studies, when found in natural archives such as soil, sediments or peat.
\end{abstract}

Keywords: Asteraceae, soil, biomarkers, pentacyclic triterpenyl acetates.

\title{
1. Introduction
}

Understanding ecosystem response under natural (climatic) and anthropogenic constraints is of crucial importance for anticipating the consequences of current global change (Dearing, 2006). Land use changes have direct consequences for the budget of greenhouse gases at the global scale. At a more local scale, it has been demonstrated that soil properties result from a long history of land use (Hurtt et al., 2006). The reconstruction of recent land use change can be approached through historical archives. For example, the impact of drastic land use change on biodiversity is particularly well documented for the middle mountains of the French Massif Central during the twentieth century (Chassagne, 1956; Antonetti, 2006). 
With respect to more ancient times, the scarcity of reliable written sources necessitates an investigation of natural archives (lake sediments, peat and speleothems) in order to unravel past natural and anthropogenic impacts on environments. These environmental records retain information about such interactions in a well constrained time frame. Deciphering such interactions involves reconstruction of ancient land use via multidisciplinary studies (e.g. palaeoecology, archaeology, sedimentology; e.g. Berglund, 1991) that provide different and complementary information.

While the potential of sediments as natural archives has largely been demonstrated, soil, although a fundamental substrate ofor human subsistence and direct support of agricultural practices, has not received comparable interest. Soil is known to be disturbed in terms of physical properties, organic matter $(\mathrm{OM})$ content and thereby of fertility when affected by land use change (Rumpel et al., 2009). The after effects of such changes remain perceptible in terms of biodiversity, and of chemical and structural soil properties, at least at the historical scale (Dupouey et al., 2002). However, only a few studies have focussed on the direct recording of land use at the molecular level (e.g. van Bergen et al., 1997; Bull et al., 1998). These studies have shown that the lipid content is directly linked to the current overlying vegetation, since the major part of the soil lipids originates from plants and is well preserved (e.g. Dinel et al., 1990; van Bergen et al., 1997; Bull et al., 1998). This makes them a reliable tool as molecular biomarkers, i.e. as compounds preserved intact or slightly modified in natural archives (and aerosols), the structure of which allows unequivocal identification of their biological source (e.g. van Bergen et al., 1997; Oros and Simoneit, 2001a,b; Simoneit, 2002, 2004; Killops and Killops, 2004). Such molecular markers benefit from 
increasing interest for studies dealing with vegetation change or human activity (e.g. Hjulström and Isaksson, 2009).

Amongst these, pentacyclic triterpenes are of special interest for organic geochemists exploring the distributions of lipids in soil, sediments and peat as remnants of past vegetation. For example, those with a lupane, oleanane or ursane structure, as well as their diagenetic derivatives, in soil and sediments are classically used as tracers of angiosperms (Cranwell, 1984; Jacob et al., 2007). However, as a result of their wide structural (skeletal) diversity (oleanane, ursane, lupane, taraxerane...), potential isomerism and associated functional groups, several recent studies have shown that, in favourable cases, pentacyclic triterpenes can be discriminant for more constrained taxa. For example, Gramineae are the most common producers of pentacyclic triterpenes bearing a MeO group at C-3 (Ohmoto et al., 1970; Jacob et al., 2005; Zocatelli et al., 2010). In particular, more specific relationships can be established, such as that allowing the linking of miliacin (olean-18-en-3 $\beta$-ol methyl ether) in sediments from Lake le Bourget (French Alps) to Panicum miliaceum (broomcorn millet) cultivated in the watershed (Jacob et al., 2008, 2009).

Here we report the presence of a series of pentacyclic triterpenyl acetates in a soil developed under pasture in the catchment of Lake Aydat (Massif Central, France). Following description of the different compounds analysed by way of gas chromatography-mass spectrometry (GC-MS), we discuss their potential biological sources and finally evaluate their potential for palaeoenvironmental studies.

\section{Setting, materials and methods}

\subsection{Location and general context}


Lake Aydat is ca. $25 \mathrm{~km} \mathrm{SW}$ of Clermont-Ferrand, in the volcanic French Massif Central. The small catchment of the lake (ca. $\left.30 \mathrm{~km}^{2}\right)$ is at an altitude ranging from 825 m (lake level) to ca. 1,300 $\mathrm{m}$ above sea level (a.s.1.). The tops of the volcanoes, the highest points, are covered by coniferous forest (mainly of Picea sp.), whereas the slopes are covered by pasture/grassland and, to a lesser extent, shrubs. The geology, relating mainly to a volcanic origin, led to the development of andisoils as a result of rapid chemical erosion in the presence of OM (Jones et al., 2005). Typically, a homogeneous organo-mineral sandy-silty horizon A developed above the $\mathrm{C}$ horizon. These slightly acidic soils are well drained and quite shallow $(<30 \mathrm{~cm})$.

\subsection{Materials and methods}

A total of 35 soil samples were taken from the lake catchment in the autumn of 2008. They represent the diversity of land use, as described above, and were collected at different altitude and orientation, so that each condition prevailing in the catchment was taken into account. In the absence of recognizable layers, soils were sub-sampled in slices $2 \mathrm{~cm}$ thick. The 0-2 and 2-4 cm depth slices were analysed in random order, since they were considered the most representative of the current vegetation cover.

Samples were dried at $40{ }^{\circ} \mathrm{C}$ for $48 \mathrm{~h}$ in an oven, crushed in a mortar and sieved at $2 \mathrm{~mm}$. An aliquot (ca. $2 \mathrm{~g}$ ) of each was extracted by way of automatic solvent extraction with a Dionex ${ }^{\circledR}$ ASE 200 using $\mathrm{CH}_{2} \mathrm{Cl}_{2}: \mathrm{MeOH}$ (1:1). After removal of the solvent under $\mathrm{N}_{2}$, the extract was separated into neutral, acidic and polar fractions on aminopropyl-bonded silica as described by Jacob et al. (2005). The neutral fraction was further separated into aliphatics, aromatics, ethers and esters, ketones and acetates, and alcohols by way of flash chromatography with a Pasteur pipette filled with activated 
silica $\left(24 \mathrm{~h}\right.$ at $120{ }^{\circ} \mathrm{C}$, then deactivated with $\left.5 \% \mathrm{H}_{2} \mathrm{O}\right)$ and using a sequence of solvents of increasing polarity. The fraction containing triterpenyl acetates and ketones was eluted with a mixture of hexane:EtOAc (9:1) and $5 \alpha$-cholestane was added prior to analysis via GC-MS with a TRACE-GCQ Polaris. The GC instrument was fitted with a Rtx-5MS column (30 m x $0.25 \mathrm{~mm}$ i.d., $0.25 \mu \mathrm{m}$ film thickness; $5 \mathrm{~m}$ column guard). The operating conditions were: $40{ }^{\circ} \mathrm{C}(1 \mathrm{~min})$ to $120^{\circ} \mathrm{C}$ at $30{ }^{\circ} \mathrm{C} \mathrm{min}{ }^{-1}$, then from $120^{\circ}$ to $300{ }^{\circ} \mathrm{C}$ (held $30 \mathrm{~min}$ ) at $5{ }^{\circ} \mathrm{C} \mathrm{min}^{-1}$. Samples were injected in splitless mode, with the injector at $280{ }^{\circ} \mathrm{C}$. He was the carrier gas at a constant flow of $1 \mathrm{ml} \mathrm{min}^{-1}$. The mass spectrometer was operated in the electron ionization (EI) mode at $70 \mathrm{eV}$ and scanned from $\mathrm{m} / z, 50$ to 600 . Component identification was based on comparison of retention times and mass spectra with authentic standards. The concentration of triterpenyl acetates was estimated by measuring peak areas in ion chromatograms. After calculating a correction factor between the peak area on the specific ion chromatogram and the peak area on the total ion current (TIC) chromatogram, the TIC area of triterpenyl acetates was measured relative to that of the standard (5a-cholestane) and to the mass of sample extracted. The identification of all compounds, except isopichierenyl acetate, was confirmed using authentic standards.

\section{Results}

This study reports on the triterpenyl acetates in a single soil sample that showed the widest diversity among the 35 samples. Variation in the distributions, probably reflecting various changes in biological input resulting from local conditions in the catchment, are not discussed here. 
Fifteen triterpenyl acetates eluted in the $44-52$ min $t_{R}$ range under our GC conditions (Fig. 1). The structures discussed are displayed together with the mass spectra in Fig. 2.

The spectra of all triterpenyl acetates display ions at $\mathrm{m} / \mathrm{z} 468,453,393408$ $\left([\mathrm{M}+],\left[\mathrm{M}^{+}-15\right],\left[\mathrm{M}^{+}-60\right]\right.$, i.e. loss of the acetate group, and $\left[\mathrm{M}^{+}-60-15\right]$, respectively), with an intensity depending on the compound. Compounds 1, 2, 3 and 6 elute in the 4447 min $t_{R}$ range and are characterised by intense $m / z, 189,203,204$ and 218 fragments attesting to a taraxerane, oleanane or ursane structure (Shiojima et al., 1992). Considering the relative retention times, 2, 3 and 6 were assigned as olean-13(18)-en$3 \beta$-yl acetate ( $\delta$-amyrin acetate), olean-12-en-3 $\beta$-yl acetate ( $\beta$-amyrin acetate) and urs12-en-3 $\beta$-yl acetate ( $\alpha$-amyrin acetate) respectively, whereas the rather intense fragments at $\mathrm{m} / \mathrm{z}, 269,329$ and 344 in the spectrum of compound 1 attest to a tarax-14en-3 $\beta$-yl acetate (taraxeryl acetate) structure.

The spectra of 10 and 11 are also characterized by intense fragments at $m / z 189$ and 204. Their late elution time vs. 2 and 3, combined with the presence of an ion at $\mathrm{m} / \mathrm{z}$ 249 , allowed identification of 10 as taraxast-20-en-3 $\beta$-yl acetate ( $\psi$-taraxasteryl acetate) and 11 as taraxast-20(30)-en-3 $\beta$-yl acetate (taraxasteryl acetate). This assignment was confirmed by comparison with authentic standards.

Intense fragments at $\mathrm{m} / \mathrm{z} 259$ and 274 in the spectrum of 5 are diagnostic for D:B-friedo-oleanane structures (Shiojima et al., 1992), consistent with glutin-5-en-3 $\beta$-yl acetate (glutinyl acetate).

The spectra of 4, 8, 9, 12, 13 and 15 are characterized by intense ion at $m / z 229$, 289, 241 and 301, with a minor contribution from ions at $m / z, 255$ and 393 (Fig. 2).

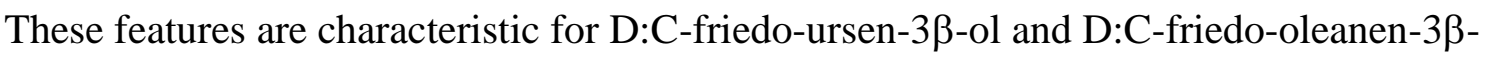


ol acetates (bauerenyl and multiflorenyl acetates, respectively) and are also found in swertenyl acetates (Shiojima et al., 1992). The use of authentic standards and relative retention times allowed assignment of 4 as bauer-8-en-3 $\beta$-yl acetate (isobauerenyl

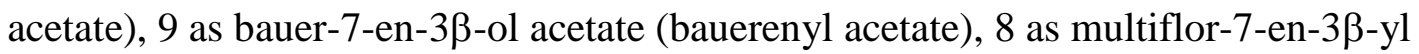
acetate (multiflorenyl acetate), 12 as pichier-8-en-3 $\beta$-yl acetate (isopichierenyl acetate -

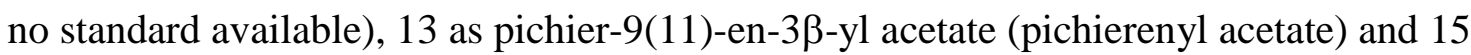
as pichier-7-en-3 $\beta$-yl acetate (swertenyl acetate). Finally, 7 was assigned as lup-20(29)-

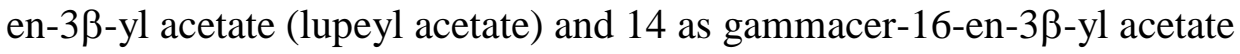
(gammacerenyl acetate) on the basis of their mass spectra (Shiojima et al., 1992) and authentic standards.

Taraxeryl acetate $(1.10 \mu \mathrm{g} / \mathrm{g}$ soil $)$, pichierenyl acetate $(0.91 \mu \mathrm{g} / \mathrm{g}$ soil $)$, glutinyl acetate $(0.81 \mu \mathrm{g} / \mathrm{g}$ soil $)$, taraxasteryl acetate $(0.29 \mu \mathrm{g} / \mathrm{g}$ soil $), \psi$-taraxasteryl acetate $(0.07 \mu \mathrm{g} / \mathrm{g}$ soil $)$ and isopichierenyl acetate $(0.54 \mu \mathrm{g} / \mathrm{g}$ soil $)$ were the most abundant compounds in the sample. In all the other samples, the concentration rarely reach $1 \mu \mathrm{g} / \mathrm{g}$ soil. For comparison, the concentrations in plants range from a few tens of $\mu \mathrm{g}$ to a few mg per gram dried plant, with a strong variability as to whether roots or aerial parts are considered (i.e. Bohlmann et al., 1981; Shiojima et al., 1989b; Lu et al., 1994; Tsao et al., 2008).

\section{Discussion}

\subsection{Distribution of triterpenyl acetates in plants}

Our literature survey of triterpenyl acetates sources led to an inventory of $>460$ plants known to produce these compounds. Most information concerning Asteraceae (432 species among the 460) was extracted from the "Bohlmann Files" database 
(Jakupovic et al., 2011), which concerns all the natural components of this family. This information was completed with other data on the distribution of triterpenyl acetates in Asteraceae. Additional data on the occurrence of the compounds in other plant taxa allowed testing of the chemotaxonomical value of the different triterpenyl acetates. Depending on bibliographical source, the degree of detail is highly variable for the different taxa. The resulting database evidently suffers from bias linked to a more specific interest toward a given plant taxa or a given chemical family. Nevertheless, the inventory provides key information on the distribution of pentacyclic triterpenyl acetates in plants.

The most commonly reported triterpenyl acetates are lupeyl acetates, comprising lup-20(29)-en-3ß-yl acetate, lup-19(20)-enyl acetate, tarolupenyl acetate [lup-19(21)-

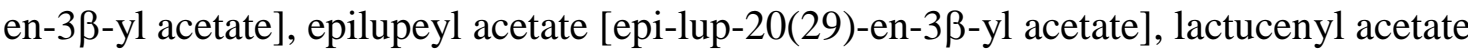
(D-friedo-lup-14-en-3ß-yl acetate; Shinozaki et al., 2011) and neolupenyl acetate (lup12-en-3 $\beta$-yl acetate), the first being by far the most reported. Of the Asteraceae, 416 species are reputed to contain lupeyl acetates (Jakupovic et al., 2011; Madrigal et al., 1975), but this component is also present in various other families such as Amaranthaceae, Cucurbitaceae, Euphorbiaceae, Moraceae and Apocynaceae (e.g. Jewers and Manchada, 1970; Dutta and Ray, 1972; Woldu et al., 1988; Yoshizumi et al., 1998; Medeiros et al., 2001; Gasparetto et al., 2010). Taraxasteryl and $\psi$ taraxasteryl acetates were overwhelmingly detected in Asteraceae, with 153 and 29 occurrences, respectively (Dutta and Ray, 1972; Madrigal et al., 1975; Jordon-Thaden and Louda, 2003; Jakupovic et al., 2011) and also in a few Apocynaceae (6 and 2 occurrences, respectively; Jewers and Manchada, 1970; Thakur et al., 1984; Abbott et al., 1990; Sen et al., 1992; Medeiros et al., 2001; Zhang et al., 2006; Yin et al., 2007; 
Pereira et al., 2008). Bauerenyl acetate was found in three Asteraceae spp., four Apocynaceae and Euphorbia chrysocoma (Cava et al., 1967; Cicció-Alberti and Hoet, 1981; Lao et al., 1983; Shi et al., 2005; Pereira et al., 2008; Jakupovic et al., 2011). Isobauerenyl acetate was only found in Euphorbia fischeriana (Liu et al., 2001) and in two Asteraceae spp.: Picris hieracioides (Shiojima et al., 1989a) and Centaurea aspera (Picher et al., 1985); $\delta$-amyrin acetate occurs in three Asteraceae spp.: Vernonia cinerea (Misra et al., 1984), Inula britannica and Echinops echinatus (Jakupovic et al., 2011) and in the Phyllanthaceae sp., Phyllanthus polyanthus (Ndlebe et al., 2008).

The biosynthesis of lupeyl, taraxasteryl, $\psi$-taraxasteryl, bauerenyl, as well as that of isobauerenyl acetates therefore appears almost exclusively constrained to Asteraceae. The lack of data concerning $\delta$-amyrin acetate does not allow discussion of its specificity. Remarkable is the detection of pichierenyl, isopichierenyl, gammacer-16en-3ß-yl and swertenyl acetates in our soil samples since these compounds have only been described in the roots of the hawkweed oxtongue Picris hieracioides (Shiojima et al., 1989a,b; 1995).

Although taraxeryl and $\beta$-amyrin acetates are also found in Asteraceae ( 9 and 29 spp., respectively; Yang et al., 1994; Madrigal et al., 1975; Jakupovic et al., 2011), they were also detected in various taxa such as Apocynaceae, Aceraceae, Euphorbiaceae, Crassulaceae, Betulaceae and Moraceae (e.g. Dutta and Ray, 1972; Stevens et al., 1994a; b; van Bergen et al., 1997; Vilegas et al., 1997; Wada et al., 1998; Pereira et al., 2008). Multiflorenyl acetate was found in Cirsium sp. and Ixeris chinensis (Asteracae; Ulubelen and Berkan, 1977; Shiojima et al., 1994; Kataria, 1995; Jakupovic et al., 2011), as well as in Tabernaemontana longipes (Apocynaceae; Cicció-Alberti and Hoet, 1981), Euphorbia guyoniana (Euphorbiaceae; Haba et al., 2007), Sedum brevifolium 
and S. meyeri-johannis (Stevens et al., 1994a), and in Polypodium niponicum (Polypodiaceae; Ageta and Arai, 1983). $\alpha$-Amyrin acetate was described in 11 Asteraceae spp. (Jakupovic et al., 2011), but also in various families such as Apocynaceae spp. [e.g. Tabernaemontana laeta (Medeiros et al., 2001), Crassulaceae (Stevens et al., 1994a), Sapotaceae (e.g. Pouteria tomentosa; Anjaneyulu, 1965), Moraceae (e.g. Antiaris africana; Okogun et al., 1976), or Balanophoraceae (Balanophora abbreviate; Yadagiri et al., 1984)]. Therefore, taraxeryl, $\beta$-amyrin, $\alpha$ amyrin and multiflorenyl acetates cannot be considered as being specific of Asteraceae. Finally, glutinyl acetate has not been reported in Asteraceae but has been in Kalanchoe daigremontiana (Crassulaceae; van Maarseveen and Jetter, 2009), Acer mandschuricum (Aceraceae; Ding et al., 2010), Erythrophleum fordii (Fabaceae; Tsao et al., 2008), as well as in Dorstenia sp. and Maquira coriacea (Moraceae; Woldu et al., 1988; MitaineOffer et al., 2001).

\subsection{Comparison of soil triterpenyl acetate diversity with local plant sources}

According to the survey by Antonetti et al. (2006), 97 species of Asteraceae occur in the catchment of Lake Aydat, ten being reputed to produce triterpenyl acetates (Table 2): the greater burdock (Arctium lappa), the musk thistle (Carduus nutans), the creeping thistle (Cirsium arvense), the mouse-ear hawkweed (Hieracium pilosella), the cotton thistle (Onopordum acanthium, the bristly oxtongue (Picris echioides), the hawkweed oxtongue (Picris hieracioides), the goldenrod (Solidago virgaurea), the common sowthistle (Sonchus oleraceus) and the dandelion (Taraxacum sp.).

Picris hieracioides, largely present in the area, appears as the most evident primary source of triterpenyl acetates in our samples because it is the only plant reputed 
to produce isopichierenyl, pichierenyl, swertenyl and gammacer-16-en-3 $\beta$-yl acetates (Shiojima et al., 1989a; b). Because it also produces $\alpha$-amyrin, $\beta$-amyrin, lupeyl, bauerenyl, isobauerenyl, taraxasteryl and $\psi$-taraxasteryl acetates (Shiojima et al., 1989a; b; 1995), it could also have contributed to these compounds in soil.

Other local sources of $\beta$-amyrin acetate from Asteraceae can alternatively be provided by Cirsium arvense (Tulloch and Hoffman, 1982) and Solidago virgaurea (Choi et al., 2004). Similarly, taraxasteryl acetate can be produced by up to seven species of Asteraceae encountered in the catchment (Arctium lappa, Carduus nutans, Cirsium arvense, Onopordum acanthium, Sonchus oleraceus and Taraxacum officinale; Jakupovic et al., 2011; Jordon-Thaden and Louda, 2003; Dutta and Ray, 1972; Khalilova et al., 2004; Hänsel et al., 1980). $\psi$-Taraxasteryl acetate is also synthesised by Cirsium arvense (Tulloch and Hoffman, 1982), whereas lupeyl acetates are found in Cirsium arvense, Hieracium pilosella, Picris echioides and Sonchus oleraceus (Tulloch and Hoffman, 1982; Jakupovic et al., 2011).

Most of the triterpenyl acetate distribution in our soil sample can thus be explained by Asteraceae species found in the surrounding vegetation, except for taraxeryl, glutinyl, multiflorenyl and $\delta$-amyrin acetates (Table 2). Because current knowledge of the distribution of these compounds does not allow explanation of their presence in our sample, alternative explanations can be invoked, each exemplified by one or two compounds:

(i) Taraxeryl, glutinyl, $\delta$-amyrin and multiflorenyl acetates may be produced by other Asteraceae spp. that occur in the catchment but have not yet benefitted from a complete phytochemical survey. Due to their belonging to genera in which other species are 
known to synthesize triterpenyl acetates, they are likely to do so as well (Table 2). In addition to Cirsium arvense, six Cirsium spp. have been described in the Lake Aydat catchment (C. acaule, C. dissectum, C. eriophorum, C. erisithales, C. palustre and $C$. vulgare; Antonetti et al., 2006), but whose pentacyclic triterpenyl acetate content has not been investigated. Because multiflorenyl acetate was described in Cirsium sp. and C. benedictus (Asteraceae; Ulubelen and Berkan, 1977; Kataria, 1995), it is tempting to suppose that one of the Cirsium spp. in the catchment could also produce multiflorenyl acetate. Similarly, because taraxeryl acetate was described in Artemisia dalailamae (Yang et al., 1994), it could possibly originate from Artemisia verlotiorum or A. vulgaris (Asteraceae), both reported in the area. Likewise, $\delta$-amyrin acetate was described in Inula britannica, while another species of the genera, I. conyza, grows in the area and could therefore be the source of this compound in the soil sample.

(ii) The compounds are produced by plants other than Asteraceae in the catchment. If the two preceding examples can help clarify the presence of taraxeryl, $\delta$-amyrin and multiflorenyl acetates, they cannot account for the presence of glutinyl acetate. According to phytochemical data, this compound is only described in Erythrophleum fordii (Fabaceae: Tsao et al., 2008), Kalanchoe daigremontiana (Crassulaceae: van Maarseveen and Jetter, 2009), Acer mandshuricum (Aceraceae: Ding et al., 2010), Dorstenia sp. and Maquira coriacea (Moraceae: Woldu et al., 1988; Mitaine-Offer et al., 2001), none of these species or genus being found in the catchment except for Acer sp. (A. pseudoplatanus, A. campestre subsp. campestre and A. platanoides; Antonetti et al., 2006). In the area, the occurrence of Acer species could thus explain the presence of glutinyl acetate in the soil sample. 
(iii) The compounds are produced by one or several of the already identified potential sources of triterpenyl acetates. Asteraceae spp. developed around Lake Aydat could synthesize distinct triterpenyl acetates distinct from those in the same species cited in the literature. Such a variability in chemodemes (i.e. biochemical races - plants from the same species producing distinct chemicals depending on location, environmental conditions or slight genetic differences) have, for example, been described for pentacyclic triterpene methyl ethers in New Zealand (Connor and Purdie, 1976). (iv) Pentacyclic triterpenes are reputed to suffer structural rearrangements and double bond migration during diagenesis that could affect the original diversity of compounds (e.g. Rullkötter et al., 1994). This phenomenon, well documented from laboratory experiments for compounds the oleanane series (Courtney et al., 1958; Coates et al., 1967), is also observed in sedimentary records (Rullkötter et al., 1994). Precisely, friedel-3-ene, glutin-5-ene, multiflor-7-ene and taraxer-14-ene are progressively rearranged to olean-18-ene, olean-12-ene and finally olean-13(18)-ene isomers. Such rearrangements have also been reported for the hopane and fernane series (Nishimoto et al., 1968) in rock and sediment samples (Volkman et al., 1986; Paul et al., 1998). To our knowledge, the only studies about such reactions on triterpenyl acetates that carried out in the laboratory (Chatterjee et al.; 1976), showed the acid-induced transformation of taraxeryl acetate to $\beta$-amyrin acetate, which could further be transformed to $\delta$-amyrin acetate. To our knowledge, the stability of pichierenyl or swertenyl acetates in natural environments remains to be checked. Thus, in the absence of available evidence, the possibility of rearrangements of triterpenyl acetates in soils can be excluded, further 
work being needed to ascertain whether this conclusion could be extended to sediments, especially over a long duration.

\subsection{Potential palaeoenvironmental implications}

Few studies have reported the occurrence of triterpenyl acetates in soil and sediments (Logan et al., 1995; van Bergen et al., 1997; Xu et al., 2008; Oyo-Ita et al., 2010; Trendel et al., 2010). According to Oyo-Ita et al. (2010), this lack can be explained by the procedures generally applied, saponification entailing loss of the acetate group. These authors also underline the possibility of natural hydrolysis of the ester bond during riverine transport. They therefore attribute the presence of triterpenyl acetates in sediments to a local source. Despite the few reports, no origin was proposed for the compounds, probably because, except for lupeyl acetates, those detected (taraxeryl, germanicyl, $\delta$-amyrin, $\beta$-amyrin acetates) were not of direct taxonomical interest. To our knowledge, our work constitutes the first report on bauerane, taraxastane, swertane and pichierane acetates in soil, which can be unequivocally linked to Asteraceae.

Asteraceae are defined as meadow and pasture species (semi-open to open habitats) that colonize disrupted environments and are able to invade fallow land developed on abandoned arable land (Cronquist, 1980; Bouby and Billaud, 2001, 2005; Antonetti et al., 2006). Their pollen is frequently used as an anthropogenic indicator because it is found mainly in settlements next to cultivated fields, in mowed or grazing places, or in ruderal communities (i.e. growing in rubbles; Hicks, 1992; Court-Picon et al., 2006). Thus, the detection of triterpenyl acetates in soil and sediments could attest to 
both open vegetation and major perturbation in the catchment, under natural but more obviously anthropogenic influence.

The compounds could constitute diagnostic tracers of agriculture and other human activities. For example, the presence of various Asteraceae seeds in a Late Bronze Age (905-869 BC) settlement on the shore of Lake le Bourget was related to their ethnobotanical properties, their consumption as human food or livestock fodder, dye and/or medicine (Bouby and Billaud, 2001; 2005). Triterpenyl acetates thus extend the panel of biomarkers for past flora that can attest, in favourable cases, to human activities such as miliacin for millet (Jacob et al., 2008), other pentacyclic triterpene methyl ethers for Gramineae (Ohmoto et al., 1970; Jacob et al., 2005; Zocatelli et al., 2010), iso- and anteiso- monomethyl alkanes for culinary and aromatic herbs from the Lamiaceae family (Huang et al., 2011) and more generally those reported by Evershed (2008) with respect to archaeology. As with these other biomarkers, triterpenyl acetates can constitute a reliable tool for tracing the presence of plants of economic interest. They could reinforce other widely used techniques that allow detection of the presence of Asteraceae in any sedimentary or archaeological context: for example, for palynological studies that suffer from the under representation of Asteraceae in pollen records because of their dispersal mode (Andrieu et al., 1997).

\section{Conclusions}

Neutral lipids in soils developed under pasture and meadow exhibit a wide array of pentacyclic triterpene structures bearing an acetate group at C-3. Among these, C-3 acetates with bauerane, taraxastane, swertane and pichierane skeletons are reported in natural archives for the first time. An exhaustive review of the phytochemical literature 
allowed us to unequivocally attribute some of the triterpenyl acetates to a single vegetation source within the Asteraceae family. This specificity confers to these compounds a high potential as tracers of Asteraceae - and thus of open environments for palaeoenvironmental studies.

\section{Acknowledgments}

The study was supported by the Erode project funded by the INSU/CNRS and Otarie project funded by the Région Centre and the European Council. M.L. also acknowledges the Région Centre for a PhD grant. We thank S. Abrams and K. Nelson (National Research Council of Canada's Plant Biotechnology Institute, Canada) for providing reference compounds from the Professor Tulloch collection, M. Benkhaled (Batna University, Algeria) for multiflorenyl acetate and Professor A. Salatino (São Paulo University, Brazil) for bauerenyl acetate. We also greatly appreciate the help

provided by Professor W. Berensohn (Botanical Garden and Botanical Museum, Berlin, Germany), project director of the Bohlmann Files. We are grateful to H.M. Tablbot and two anonymous reviewer for corrections and constructive comments. 


\section{References}

Abbott, T.P., Peterson, R.E., Tjarks, L.W., Palmer, D.M., Bagby, M.O., 1990. Major extractable components in Asclepias linaria (Asclepiadaceae) and Ilex verticillata (Aquifoliaceae), two potential hydrocarbons crops. Economic Botany 44, 278284.

Ageta, H., Arai, Y., 1983. Fern constituents: pentacyclic triterpenoids isolated from Polypodium niponicum and P. formosanum. Phytochemistry 22, 1801-1808.

Ahmad, V.U., Fizza, K., 1986. Chemical constituents of Euphorbia granulaia. Fitoterapia 57, 280

Ahmad, V.U., Ismail, N., 1991. 5-Hydroxy-3,6,7,2',5'-pentamethoxyflavone from Inula grantioides. Phytochemistry 30, 1040-1041.

Andrieu, V., de Beaulieu, J.L., Ponel, P., Reille, M., 1997. Les distorsions de l'enregistrement pollinique de l'histoire de la végétation du dernier cycle climatique: exemples de séquences lacustres du Sud de la France. Geobios 21, 195-202.

Anjaneyulu, B., 1965. Chemical investigation of some Indian plants. Indian Journal of Chemistry 3, 237-238.

Antonetti, P., Brugel, E., Kessler, F., Barbe, J.P., Tort, M., 2006. Atlas de la Flore d'Auvergne. Conservatoire botanique national du Massif Central, ChavaniacLafayette (France).

van Bergen, P., Bull, I., Poulton, P.R., Evershed, R.P., 1997. Organic geochemical studies of soils from the Rothamsted Classical Experiments--1. Total lipid extracts, solvent insoluble residues and humic acids from Broadbalk Wilderness. Organic Geochemistry 26, 117-135. 
Berglund, B.E., 1991. The cultural landscape during 6000 years in southern Sweden: the Ystad Project. Ecological Bulletin 41, 495 pp.

Bohlmann, F., Müller, L., King, R.M., Robinson, H., 1981. A guaianolide and other constituents from Lychnophora species. Phytochemistry 20, 1149-1151.

Bouby, L., Billaud, Y., 2001. Economie agraire à la fin de l'âge du Bronze sur les bords du Lac du Bourget (Savoie, France). Comptes Rendus de l'Académie des Sciences II A $333,749-756$.

Bouby, L., Billaud, Y., 2005. Identifying prehistoric collected wild plants: a case study from Late Bronze Age settlements in the French Alps (Grésine, Bourget Lake, Savoie). Economic Botany 59, 255-267.

Bull, I.D., van Bergen, P.F., Poulton, P.R., Evershed, R.P., 1998. Organic geochemical studies of soils from the Rothamsted Classical Experiments - II, Soils from the Hoosfield Spring Barley Experiment treated with different quantities of manure. Organic Geochemistry 28, 11-26.

Cava, M.P., Shubber, A.K., Rao, K.V., 1967. Triterpene constituents of Tabernaemontana laurifolia and Haplophyton cimicidum. Phytochemistry 6, 1301-1303.

Chassagne, M., 1956. Inventaire Analytique de la Flore d'Auvergne et Contrées Limitrophes des Départements Voisins. Tome 1. P. Lechevalier, Paris.

Chatterjee, A., Mukhopadhyay, S. et Chattopadhyay, K., 1976. Lewis acid catalysed rearrangement of triterpenoids. Tetrahedron 32, 3051-3053.

Choi, S.Z., Choi, S.U., Lee, K.R., 2004. Phytochemical constituents of the aerial parts from Solidago virga-aurea var. gigantean. Archives of Pharmacal Research 27, 164-168. 
Cicció-Alberti, J.F., Hoet, P., 1981. Algunos constituyentes de los frutos y de las hojas de Tabernaemontana longipes Donn. Smith. Congreso Latinoamericano de Química. XV, San José, CR, Febrero 1981, 89-90.

Coates, R. M., 1967. On the friedelane-oleanane rearrangement. Tetrahedron Letters 42, 4143-4146.

Connor, H.E., Purdie, A.W., 1976. Triterpene methyl ether differentiation in Chionochloa (Gramineae). New Zealand Journal of Botany 14, 315-326.

Court-Picon, M., Buttler, A., de Beaulieu, J.L., 2006. Modern pollen/vegetation/land use relationships in mountain environments: an example from the Champsaur valley (French Alps). Vegetation History and Archaeobotany 15, 151-168.

Courtney, J. L., Gascoigne, R. M., Szumer, A. Z., 1958. Triterpenoids of the friedelane series. Part III. The course of friedelane-oleanane rearrangement. Journal of the Chemical Society, 881-886.

Cranwell, P.A., 1984. Organic geochemistry of lacustrine sediments: triterpenoids of higher plant origin reflecting post-glacial vegetational succession. In: Haworth, E.Y., Lund, J.W.G. (Eds.), Lakes Sediments and Environmental History. University Press, Leicester, pp. 69-92.

Cronquist A., 1980. Vascular Flora of the Southeastern United States. Volume 1: Asteraceae. University of North Carolina Press, Chapel Hill.

Dearing, J.A., 2006. Climate-human-environment interactions: resolving our past. Climate of the Past 2, 187-203.

Dinel, H., Schnitzer, M., Mehuys, G.R., 1990. Soil lipids: origin, nature, content, decomposition, and effect on soil physical properties. In: Bollag J.M., Stotzky G. (Eds.), Soil Biochemistry, vol. 6. Marcel Dekker, New York, pp. 397-426. 
Ding, Y., Liang, C., Kim, J.H., Lee, Y.M., Hyun, J.H., Kang, H.K., Kim, J.A., Min, J.A., Kim, Y.H., 2010. Triterpene compounds isolated from Acer mandshuricum and their anti-inflammatory activity. Bioorganic and Medicinal Chemistry Letters $20,1528-1531$.

Dupouey, J.L., Dambrine, E., Laffite, J.D., Moares, C., 2002. Irreversible impact of past land use on forest soil and biodiversity. Ecology 83, 2978-2984.

Dutta, C.P., Ray, L.P.K., 1972. Taraxasterol and its derivatives from Cirsium arvense. Phytochemistry 11, 2267-2269.

Evershed, R.P., 2008. Organic residue analysis in archaeology: The archaeological biomarker revolution. Archaeometry 50, 895-924.

Gasparetto, A., Lapinski, T.F., Zamuner, S.R., Khouri, S., Alves, L.P., Munin, E., Salvador, M.J., 2010. Extracts from Alternanthera maritima as natural photosensitizers in photodynamic antimicrobial chemotherapy (PACT). Journal of Photochemistry and Photobiology B: Biology 99, 15-20.

Haba, H., Lavaud, C., Harkat, H., Magid, A.A., Marcourt, L., Benkhaled, M., 2007. Diterpenoids and triterpenoids from Euphorbia guyoniana. Phytochemistry 68, 1255-1260.

Hänsel, R., Kartarahardja, M., Huang, J.T., Bohlmann, F., 1980. Sesquiterpenlacton- $\beta$ D-glucopyranoside sowie ein neues eudesmanolid ais Taraxacum officinale. Phytochemistry $19,857-861$.

Hicks, S., 1992. Modern pollen deposition and its use in interpreting the occupation history of the island Hailuoto, Finland. Vegetation History and Archaeobotany 1, 75-86. 
Hjulström, B., Isaksson, S., 2009. Identification of activity area signatures in a reconstructed Iron Age house by combining element and lipid analyses of sediments. Journal of Archaeological Science 36, 174-183.

Huang, X., Meyers, P.A., Wu, W., Jia, C., Xie, S., 2011. Significance of long chain iso and anteiso monomethyl alkanes in the Lamiaceae (mint family). Organic Geochemistry 42, 156-165.

Hurtt, G.C., Frolking, S., Fearon, M.G., Moore III, B., Shevliakova, E., Malyshev, S., Pacala, S., Houghton, R.A., 2006. The underpinnings of land use history: three centuries of global gridded land use transitions, wood-harvest activity, and resulting secondary lands. Global Change Biology 12, 1208-1229.

Jacob, J., Disnar, J.R., Arnaud, F., Chapron, E., Debret, M., Lallier-Vergès, E., Desmet, M., Revel-Rolland, M., 2008. Millet cultivation history in the French Alps as evidenced by a sedimentary molecule. Journal of Archaeological Science 35, 814820.

Jacob, J., Disnar, J.R., Arnaud, F., Gauthier, E., Billaud, Y., Chapron, E., Bardoux, G., 2009. Impacts of new agricultural practices on soil erosion during the Bronze Age in French Prealps. The Holocene 19, 241-249.

Jacob, J., Disnar, J.R., Boussafir, M., Albuquerque, A.L.S., Sifeddine, A., Turcq, B., 2007. Contrasted distributions of triterpene derivatives in the sediments of Lake Caçó reflect paleoenvironmental changes during the last 20,000 yrs in NE Brazil. Organic Geochemistry 38, 180-197.

Jacob, J., Disnar, J.R., Boussafir, M., Sifeddine, A., Albuquerque, A.L.S., Turcq, B., 2005. Pentacyclic triterpene methyl ethers in recent lacustrine sediments (Lagoa do Caçó, Brazil). Organic Geochemistry 36, 449-461. 
Jakupovic, J., Tsichrintzis, F., Zdero, C., Hahn, A., Lipp, W., Smalla, B., Berendsohn, W.G. [accessed 04/12/2011]. The Bohlmann-Files - A database of natural substances in the Compositae. http://www.bgbm.org/BioDivInf/projects/bohlmannfiles/

Jewers, K., Manchanda, A.H., 1970. The constitutents of the Apocynaceae III. The triterpenoids of Paravallaris maingayi bark. Phytochemistry 9, 2249.

Jones, A., Montanarella, L., Jones, R., 2005. Soil Atlas of Europe. European Soil Bureau Network. European Commission, Luxembourg.

Jordon-Thaden, I.E., Louda, S.M., 2003. Chemistry of Cirsium and Carduus: a role in ecological risk assessment for biological control of weeds? Biochemical Systematics and Ecology 31, 1353-1396.

Kataria H., 1995. Phytochemical investigation of medicinal plant Cnicus wallichii and Cnicus benedictus L. Asian Journal of Chemistry 7, 227-228.

Khalilova, L.M., Khalilova, A.Z., Shakurova, E.R., Nuriev, I.F., Kachala, V.V., Shashkov, A.S., Dzhemilev, U.M., 2003. PMR and ${ }^{13}$ C NMR spectra of biologically active compounds. XII. Taraxasterol and its acetate from the aerial part of Onopordum acanthium. Chemistry of Natural Compounds 39, 285-288.

Khalilova, A.Z., Litvinov, I.A., Beskrovnyi, D.V., Gubaidullin, A.T., Shakurova, E.R., Nuriev, I.R., Khalilov, L.M., Dzhemilev, U.M., 2004. Isolation and crystal structure of taraxasteryl acetate from Onopordum acanthium. Chemistry of Natural Compounds 40, 254-257.

Killops, S.D., Killops, V.J., 2004. An Introduction to Organic Geochemistry, $2^{\text {nd }}$ Edition. Blackwell Publishing, Oxford 408 pp. 
Lao, A., Fujimoto, Y., Tatsuno, T., 1983. Studies on the constituents of Artemisia rubripes Nakai. Yakugaku Zasshi 103, 696-699.

Lao, A., Fujimoto, Y., Tatsuno, T., 1984. Studies on the constituents of Artemisia argyi Levl et Vant. Chemical and Pharmaceutical Bulletin 32, 723-727.

Liu, W.Z., He, F.L., Ruan, Z.Y., Gu, X.F., Wu, X.Y., Qin, G.W., 2001. Studies on chemical constituents from Euphorbia fischeriana Steud. Zhongguo Zhong Yao Za Zhi 26, 180-182.

Logan, G.A., Smiley, C.J., Eglinton, G., 1995. Preservation of fossil leaf waxes in association with their source tissues, Clarkia, northern Idaho, USA Clarkia, northern Idaho, USA. Geochimica et Cosmochimica Acta 59, 4, 751-763.

Lu, T., Cantrell, C.L., Vargas, D., Fronczek, F.R., Franzblau, S.G., Fischer, N.H., 1994. Terpenes from Liatris ohlingerae. Phytochemistry 37, 1295-1299.

van Maarseveen, C., Jetter, R., 2009. Composition of the epicuticular and intracuticular wax layers on Kalanchoe daigremontiana (Hamet et Perr. De la Bathie) leaves. Phytochemistry 70, 899-906.

Madrigal, R.V., Plattner, R.D., Smith Jr., C.R, 1975. Carduus nigrescens seed oil - a rich source of pentacyclic triterpenoids. Lipids 10, 208-213.

Medeiros, W.L.B., Vieira, I.J.C., Mathias, L., Braz-Filho, R., Schripsema, J., 2001. A new natural quaternary indole alkaloid isolated from Tabernaemontana laeta Mart. (Apocynaceae). Journal of the Brazilian Chemical Society 12, 368-372.

Misra, T.N., Singh, R.S., Upadhyay, J., Srivastava, R., 1984. Chemical constituents of Vernonia cinerea, Part I. Isolation and spectral studies of triterpenes. Journal of Natural Products 47, 368-372. 
Mitaine-Offer, A.C., Sauvain, M., Petermann, C., Zèches-Hanrot, M., 2001.

Constituents of the trunk bark of Maquira coriacea. Fitoterapia 72, 841-843.

Ndlebe, V.J., Crouch, N.R., Mulholland, D.A., 2008. Triterpenoids from the African tree Phyllanthus polyanthus. Phytochemistry Letters 1, 11-17.

Nishimoto, K., Ito, M., Natori, S., Ohmoto, T., 1968. The structures of arundoin, cylindrin and fernenols. Triterpenoids of fernane and arborane groups of Imperata cylindrical var. koenigii. Tetrahedron $24,735-752$.

Ohmoto, T., Ikuse, M., Natori, S., 1970. Triterpenoids of the Gramineae.

Phytochemistry 9, 2137-2148.

Okogun, J.I., Spiff, A.I., Ekong, D.E.U., 1976. Triterpenoids and betaines from the latex and bark of Antiaris Africana. Phytochemistry 15, 826-827.

Oros, D.R., Simoneit, B.R.T., 2001a. Identification and emission factors of molecular tracers in organic aerosols from biomass burning Part 1. Temperate climate conifers. Applied Geochemistry 16, 1523-1544.

Oros, D.R., Simoneit, B.R.T., 2001b. Identification and emission factors of molecular tracers in organic aerosols from biomass burning Part 2. Deciduous trees. Applied Geochemistry 16, 1545-1565.

Oyo-Ita, O.E., Ekpo, B.O., Oros, D.R., Simoneit, B.R.T., 2010. Occurrence and sources of triterpenoid methyl ethers and acetates in sediments of the Cross-River system, Southeast Nigeria. International Journal of Analytical Chemistry. doi:10.1155/2010/502076.

Paul, R., Michaelsen, B.H., McKirdy, D.M., 1998. Fernenes and other triterpenoid hydrocarbons in Dicroidium-bearing Triassic mudstones and coals from South Australia. Organic Geochemistry 29, 1331-1343. 
Pereira, P.S., França, S.d.C., de Oliveira, P.V.A., de Souza Breves C.M., Vaz Pereira, S.I., 2008. Chemical constituents from Tabernaemontana catharinensis root bark: a brief NMR review of indole alkaloids and in vitro cytotoxicity. Química Nova $31,20-24$.

Picher, M.T., Seoane, E., Tortajada, A., 1985. Components of hexane extracts of the flowers of Centaurea aspera L. ssp. stenophylla (Dufour) Nyman. Anales de Quimica Serie C. Quimica Organica y Bioquimica 81, 211-21.

Rullkötter, J., Peakman, T.M., ten Haven, H.L, 1994. Early diagenesis of terrigenous triterpenoids and its implications for petroleum geochemistry. Organic Geochemistry 21, 215-233.

Rumpel, C., Chabbi, A., Nunan, N., Dignac, M.F., 2009. Impact of land use change on the molecular composition of soil organic matter. Journal of Analytical and Applied Pyrolysis 85, 431-434.

Sen, S., Sahu, N.P., Mahato, S.B., 1992. Flavonol glycosides from Calotropis gigantea. Phytochemistry 31, 2919-2921.

Shi, H.M., Long, B.S., Cui, X.M., Min, Z.D., 2005. A new bisabolane sesquiterpenoid from Euphorbia chrysocoma. Journal of Asian Natural Products Research 7, 857860.

Shinozaki, J., Nakane, T., Onodera, N., Takano, A., Masuda, K., 2011. Composite constituent: lactucenyl acetate, a novel migrated lupane triterpenoid from Lactuca indica L. Revision of structure of tarolupenyl acetate. Chemical and Pharmaceutical Bulletin 59, 767-769.

Shiojima, K., Arai, Y., Masuda, K., Takase, Y., Ageta, T., Ageta H., 1992. Mass spectra of pentacyclic triterpenoids. Chemical Pharmacology Bulletin 40, 1683-1690. 
Shiojima, K., Masuda, K., Lin, T., Suzuki, H., Ageta, H., Inoue, M., Ishida, T., 1989a. Composite constituents: three gammacer-16-ene derivatives, novel triterpenoids isolated from roots of Picris hieracioides L. subsp. Japonica. Tetrahedron Letters 30, 4977-4980.

Shiojima, K., Masuda, K., Ooishi, Y., Suzuki, H., Ageta, H., 1989b. Composite constituents: new migrated gammacerane triterpenoids from roots of Picris hieracioides L. subsp. Japonica. Tetrahedron Letters 30, 6873-6874.

Shiojima, K., Masuda, K., Suzuki, H., Lin, T., Ooishi, Y., Ageta, H., 1995. Composite constituents: forty-two triterpenoids including eight novel compounds isolated from Picris hieracioides subsp. japonica. Chemical and Pharmaceutical Bulletin $43,1634-1639$.

Shiojima, K., Suzuki, H., Kodera, N., Kubota, K.I., Tsushima, S., Ageta, H., Chang, H.C., Chen, Y.P., 1994. Composite constituent: novel triterpenoid, 17-epi-lupenyl acetate, from aerial parts of Ixeris chinensis. Chemical and Pharmaceutical Bulletin 42, 2193-2195.

Shoeb, M., Celik, S., Nahar, L., MacManus, S.M., Kong-Thu-Lin, P., Jaspars, M., Sarker, S.D., 2007. Two salonitenolide derivatives from the aerial parts of Centaurea gigantea inhibit the growth of colorectal cancer cells in vitro. Natural Products Communications 2, 121-125.

Simoneit, B.R.T., 2002. Molecular indicators (biomarkers) of past life. The Anatomical Record 268, 186-195.

Simoneit, B.R.T., 2004. A review of current applications of mass spectrometry for biomarker / molecular tracer elucidations. Mass Spectrometry Reviews 24, 719765. 
Stevens, J.F., Hart, H., Bolck, A., Zwaving, J.H., Malingré, T.M., 1994a. Epicuticular wax composition of some European Sedum species. Phytochemistry 35, 389-399. Stevens, J.F., Hart, H., Pouw, A.J.A., Bolck, A., Zwaving, J.H., 1994b. Epicuticular waxes of Sedum series Rupestria. Phytochemistry 36, 341-348.

Thakur, S., Das, P., Itoh, T., Imai, K., Matsumoto, T., 1984. Latex extractables of Calotropis gigantea. Phytochemistry 23, 2085-2087.

Trendel, J.M., Schaeffer, P., Adam, P., Ertlen, D., Schwartz, D., 2010. Molecular characterisation of soil surface horizons with different vegetation in the Vosges Massif (France). Organic Geochemistry 41, 1036-1039.

Tsao, C.C., Shen, Y.C., Su, C.R., Li, C.Y., Liou, M.J., Dung, N.X., Wu, T.S., 2008. New diterpenoids and the bioactivity of Erythrophleum fordii. Bioorganic and Medicinal Chemistry 16, 9867-9870.

Tulloch, A.P., Hoffman, L.L., 1982. Epicuticular wax of Cirsium arvense. Phytochemistry 21, 1639-1642.

Ulubelen, A., Berkan, T., 1977. Triterpenic and steroidal compounds of Cnicus Benedictus. Planta Medica 31, 375-377.

Vilegas, J.H.Y., Lanças, F.M., Vilegas, W., Pozetti, G.L., 1997. Further triterpenes, steroids and furocoumarins from Brazilian medicinal plants of Dorstenia genera (Moraceae). Journal of the Brazilian Chemical Society 8, 529-535.

Volkman, J.K., Allen, D.I., Stevenson, P.L., Burton, H.R, 1986. Bacterial and algal hydrocarbons in sediments from a saline Antarctic lake, Ace Lake. In: Leythaeuser, D., Rullkötter, J. (Eds.), Advances in Organic Geochemistry. Pergamon Press, Oxford, pp. 671-681. 
Wada, H., Tachibana, H., Fuchino, H., Tanaka, H., 1998. Three new diarylheptanoid glycosides from Alnus japonica. Chemical and Pharmaceutical Bulletin 46, 10541055.

Woldu, Y., Abegaz, B., Botta, B., Delle Monache, G., Delle Monache, F., 1988. Styrenes from Dorstenia barnimiana. Phytochemistry 27, 1227-1228.

Xu, Y., Jaffé, R., Simoneit, B.R.T., 2008. Oxygenated spiro-triterpenoids possibly related to arborenes in sediments of a tropical, freshwater lake. Organic Geochemistry 39, 1400-1404.

Yadagiri, B., Raj, K., Subba Rao, G.S.R., 1984. Triterpenoids from Balanophora abbreviata and Balanophora indica. Journal of Natural Products 47, 182-191.

Yang, F.Q., Ou, Q.Y., Yu, W.L., 1994. Chemical constituents of Artemisia dalailamae Kraschen. Zhongguo Zhong Yao Za Zhi 19, 166-167.

Yin, M., Chen, Y., Wang, M., Dong, Y.F., Xia, B., Feng, X., 2007. Chemical constituents in the root of Cynanchum auriculatum. Zhong Yao Cai 30, 12451247.

Yoshizumi, S., Murakami, T., Kadoya, M., Matsuda, H., Yamahara, J., Yoshikawa, M., 1998. Medicinal foodstuffs. XI. Histamine release inhibitors from wax gourd, the fruits of Benincasa hispida Cogn. Yakugaku Zasshi 118, 188-192.

Zhang, J.F., Li, Y.B., Li, C.L., Jiang, J.Q., 2006. Studies on chemical constituents in root tuber of Cynanchum auriculatum. Zhongguo Zhong Yao Za Zhi 31, 814-816.

Zocatelli, R., Jacob, J., Turcq, B, Boussafir, M., Sifeddine, A. Bernardes, M.C., 2010. Molecular evidence for recent turf cultivation in Northeast Brazil (Lagoa do Boqueirão, RN State). Organic Geochemistry 41, 427-430. 


\section{Table captions}

\section{Table 1}

Inventory of triterpenyl acetates in soil samples with peak number, retention time and mass spectral data.

\begin{tabular}{|c|c|c|c|c|c|}
\hline Peak & $\begin{array}{c}\text { Ret. } \\
\text { time }\left(t_{R}\right. \\
\min )\end{array}$ & Name & Trivial name & $\mathrm{M}^{+}$ & $\begin{array}{c}\text { Significant MS fragments } \\
\text { ( } \mathrm{m} / \mathrm{z} \text { decreasing abundance) }\end{array}$ \\
\hline 1 & 44.90 & Tarax-14-en-3 $\beta$-yl acetate & Taraxeryl acetate & 468 & $204,189,269,218,329,344,393,453,468$ \\
\hline 2 & 45.15 & $\begin{array}{c}\text { Olean-13(18)-en-3 } \beta \text {-yl } \\
\text { acetate }\end{array}$ & $\delta$-Amyrin acetate $\square$ & 468 & $189,205,218,204,203$ \\
\hline 3 & 45.28 & Olean-12-en-3 $\beta$-yl acetate & $\beta$-Amyrin acetate & 468 & $203,218,189,257,323,393,408,453,468$ \\
\hline 4 & 45.57 & Bauer-8-en-3 $\beta$-yl acetate & Isobauerenyl acetate & 468 & $229,289,241,257,341,393,409$ \\
\hline 5 & 46.23 & 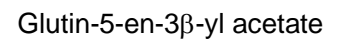 & Glutinyl acetate & 468 & $259,274,393,408,453,468$ \\
\hline 6 & 46.25 & Urs-12-en-3 $\beta$-yl acetate & $\alpha$-Amyrin acetate & 468 & $218,189,203,257,393,408,468,453$ \\
\hline 7 & 46.28 & $\begin{array}{l}\text { Lup-20(29)-en-3 } \beta \text {-yl } \\
\text { acetate }\end{array}$ & Lupeyl acetate & 468 & $189,204,218,297,355,453,468,393$ \\
\hline 8 & 47.62 & Multiflor-7-en3 $\beta$-yl acetate & Multiflorenyl acetate & 468 & $205,229,241,301,262,289$ \\
\hline 9 & 48.08 & Bauer-7-en-3 $\beta$-yl acetate & Bauerenyl acetate & 468 & $229,289,241,393,453,468$ \\
\hline 10 & 48.40 & 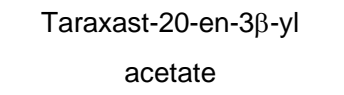 & $\begin{array}{c}\psi \text {-Taraxasteryl } \\
\text { acetate }\end{array}$ & 468 & $189,204,249,408,468,393$ \\
\hline 11 & 48.70 & $\begin{array}{c}\text { Taraxast-20(30)-en-3 } 3-\mathrm{yl} \\
\text { acetate }\end{array}$ & Taraxasteryl acetate & 468 & $189,218,204,232,249,408,262,468$ \\
\hline 12 & 49.11 & Pichier-8-en-3 $\beta$-yl acetate & Isopichierenyl acetate & 468 & $289,229,241,301,393,453,468$ \\
\hline 13 & 49.73 & 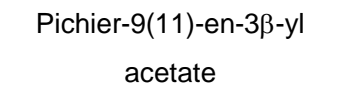 & Pichierenyl acetate & 468 & $289,301,241,229$ \\
\hline 14 & 49.86 & $\begin{array}{c}\text { Gammacer-16-en-3 } \beta \text {-yl } \\
\text { acetate }\end{array}$ & $\begin{array}{l}\text { Gammacerenyl } \\
\text { acetate }\end{array}$ & 468 & $187,191,327,408,468$ \\
\hline 15 & 51.63 & 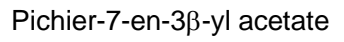 & Swertenyl acetate & 468 & $289,229,241,301,393,453,468$ \\
\hline
\end{tabular}




\section{Table 2}

Known occurrences of triterpenyl acetates found in soil sample from Lake Aydat

Catchment. $^{\mathrm{a}, \mathrm{b}}$

\begin{tabular}{|c|c|c|c|c|c|c|c|c|c|c|c|c|c|c|c|}
\hline & 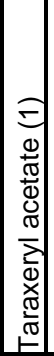 & 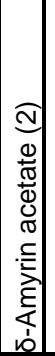 & 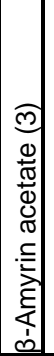 & 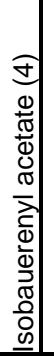 & 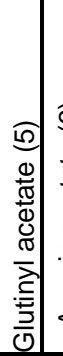 & 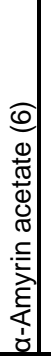 & 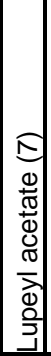 & 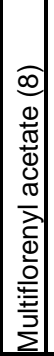 & 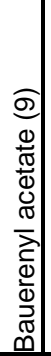 & 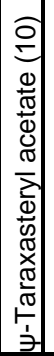 & & 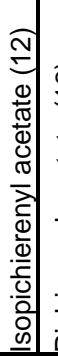 & 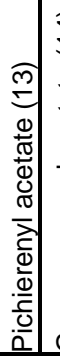 & 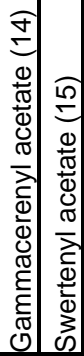 & Reference \\
\hline \multicolumn{16}{|l|}{ (a) Asteraceae species } \\
\hline Arctium lappa L. & & & & & & & & & & & $x$ & & & & \multirow{11}{*}{$\begin{array}{l}\text { Jakupovic et al., } 2011 \\
\text { Jordon-Thaden and Louda, } 2003 \\
\text { Dutta and Ray, 1972; Tulloch and Hoffman, 1982; Jakupovic et al., } 2011 \\
\text { Jakupovic et al., } 2011 \\
\text { Khalilova et al., 2003, 2004; Shoeb et al., } 2007 \\
\text { Jakupovic et al., 2011 } \\
\text { Shiojima et al., 1989a; b; 1995; Jakupovic et al., } 2011 \\
\text { Choi et al., } 2004 \\
\text { Jakupovic et al., } 2011 \\
\text { Hänsel et al., } 1980\end{array}$} \\
\hline Carduus nutans & & & & & & & & & & & $x$ & & & & \\
\hline Cirsium arvense & & & $x$ & & & $\mathrm{x}$ & $x$ & & & $x$ & $x$ & & & & \\
\hline Hieracium pilosella L. & & & & & & & $x$ & & & & & & & & \\
\hline Onopordum acanthium & & & & & & & & & & & $x$ & & & & \\
\hline Picris echioides & & & & & & & $x$ & & & & & & & & \\
\hline Picris hieracioides & & & $x$ & $x$ & & $x$ & $x$ & & $x$ & $x$ & $x$ & $x$ & $x>$ & $x \quad x$ & \\
\hline Solidago virga-aurea & & & $x$ & & & & & & & & & & & & \\
\hline Sonchus oleraceus L. & & & & & & $x$ & $x$ & & & & $x$ & & & & \\
\hline Taraxacum officinale & & & & & & & & & & & $x$ & & & & \\
\hline Total (a) & & & $x$ & $x$ & & $x$ & $x$ & & $x$ & $x$ & $x$ & $\mathrm{x}$ & $x>$ & $x \quad x$ & \\
\hline \multicolumn{16}{|l|}{ (b) Asteraceae genera } \\
\hline Artemisia (2) & $x$ & & $x$ & & & $x$ & $x$ & & $x$ & & $x$ & & & & \multirow{4}{*}{$\begin{array}{l}\text { Lao et al., 1983; 1984; Yang et al., 1994; Jakupovic et al., } 2011 \\
\text { Dutta and Ray, 1972; Ulubelen and Berkan, 1977; Tulloch and Hoffman, } \\
\text { 1982; Jakupovic et al., } 2011 \\
\text { Ahmad and Ismail, 1991; Jakupovic et al., } 2011\end{array}$} \\
\hline Cirsium (7) & & & $x$ & & & $\mathrm{x}$ & $x$ & $x$ & & $x$ & $x$ & & & & \\
\hline Inula (1) & & $x$ & & & & & $x$ & & & & $x$ & & & & \\
\hline Total $(a)+(b)$ & $x$ & $x$ & $x$ & $x$ & & $x$ & $x$ & $x$ & $x$ & $x$ & $x$ & $x$ & $x>$ & $x \quad x$ & \\
\hline \multicolumn{16}{|l|}{ (c) Other taxa } \\
\hline Acer & & & $x$ & & $x$ & & & & & & & & & & \multirow{3}{*}{$\begin{array}{l}\text { van Bergen et al., 1997; Ding et al., } 2010 \\
\text { Dutta and Ray, 1972; Ahmad and Fizza, 1986; Liu et al., 2001; Shi et al., } \\
\text { 2005; Haba et al., } 2007\end{array}$} \\
\hline Euphorbia & $\mathrm{x}$ & & $\mathrm{x}$ & $\mathrm{x}$ & $\mathrm{x}$ & & $x$ & $x$ & $\mathrm{x}$ & & $\mathrm{X}$ & & & & \\
\hline Total $(a)+(b)+(c)$ & $x$ & $x$ & $x$ & $x$ & $x>$ & $x$ & $x$ & $x$ & $x$ & $x$ & $x$ & $x$ & $x>$ & $x \quad x$ & \\
\hline
\end{tabular}

a (a) Asteraceae species in Lake Aydat catchment; (b) Asteraceae genera in which triterpenyl acetates have been described; ${ }^{b}$ numbers in parentheses refer to number of species of a given genera described in the catchment according to Antonetti et al. (2006). 


\section{Figure captions}

Fig. 1. Example of distribution of triterpenyl acetates in ketone/acetate fraction from a soil sample from catchment of Lake Aydat, under pasture. a TIC); $\mathrm{b} / \mathrm{z}$ 189+203+204+218 chromatogram; c m/z 259+274 chromatogram; d m/z 229+289 chromatogram. The MS and $t_{R}$ data and assignment of compounds 1 to 15 are given in Table 1. The spectra are provided in Fig. 2.
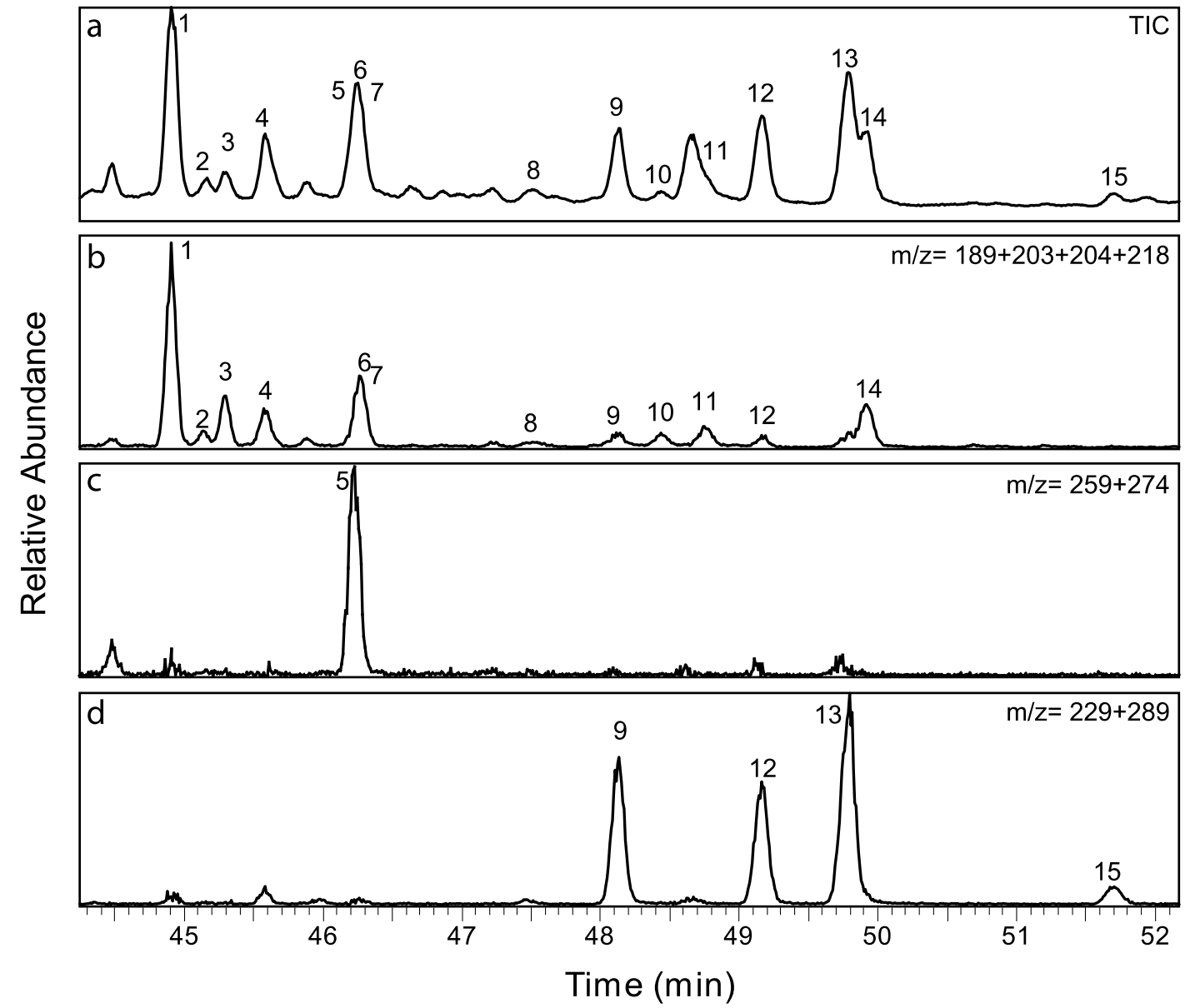
Fig. 2. Mass spectra and structure of compounds in soil sample. Numbers refer to Table 1 and Fig. 1. Mass spectra of glutinyl, $\alpha$-amyrin and lupeyl acetates were recorded for the standard compound because of GC co-elution with the soil sample.
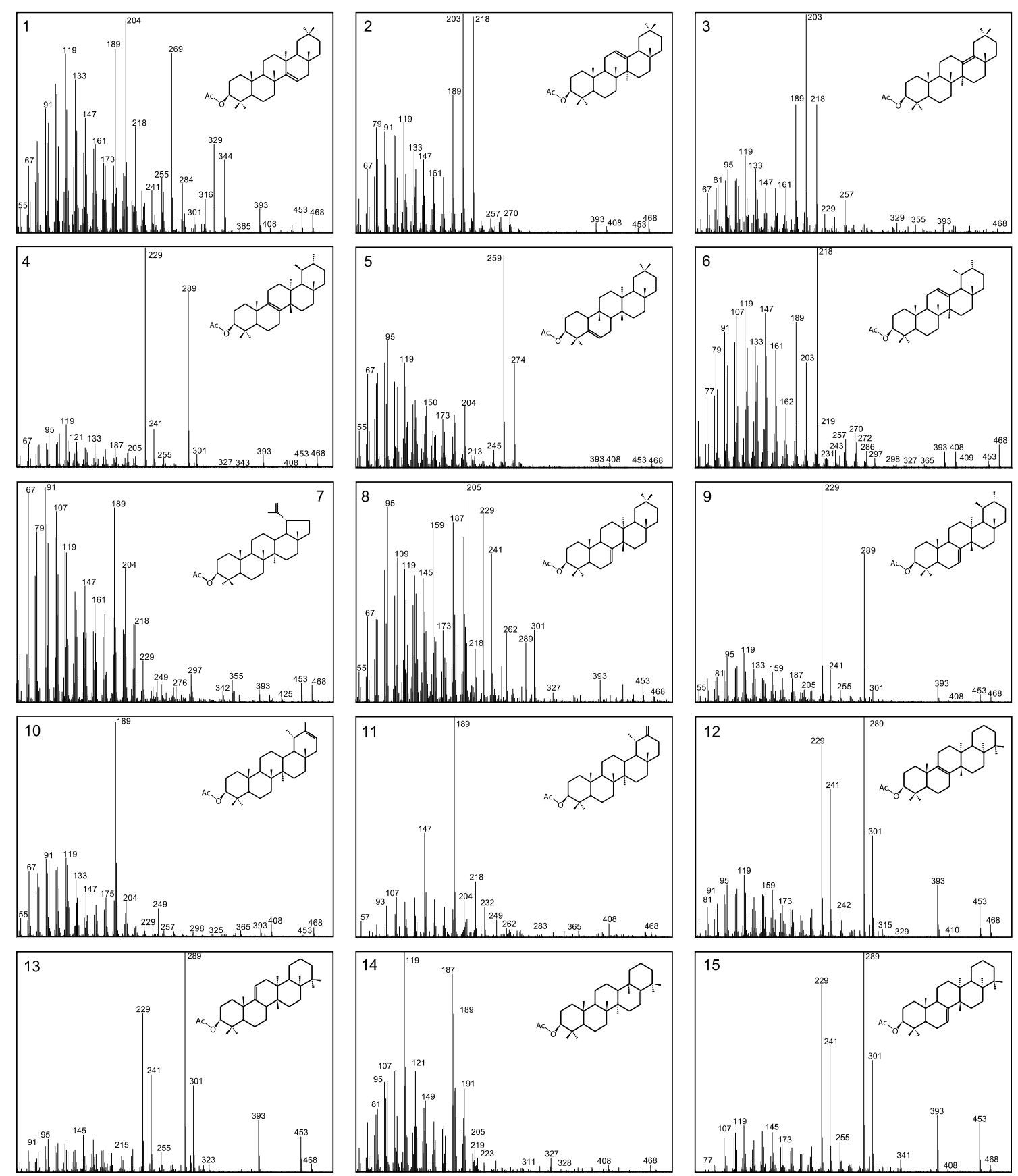